\title{
BMJ Open Economic burden of managing oral cancer patients in Sri Lanka: a cross- sectional hospital -based costing study
}

\author{
Hemantha Amarasinghe, ${ }^{\oplus 1,2}$ Ruwan Duminda Jayasinghe, ${ }^{3}$ \\ Dilantha Dharmagunawardene, ${ }^{4}$ Manjula Attygalla, ${ }^{5}$ Paul A Scuffham, ${ }^{2}$ \\ Newell Johnson, ${ }^{2,6}$ Sanjeewa Kularatna ${ }^{\bullet}$
}

To cite: Amarasinghe $\mathrm{H}$, Jayasinghe RD,

Dharmagunawardene $\mathrm{D}$, et al. Economic burden of managing oral cancer patients in Sri

Lanka: a cross-sectional hospital -based costing study. BMJ Open 2019;9:e027661. doi:10.1136/ bmjopen-2018-027661

- Prepublication history for this paper is available online. To view these files please visit the journal online (http://dx.doi. org/10.1136/bmjopen-2018027661).

Received 20 November 2018 Revised 26 April 2019

Accepted 13 June 2019

\section{Check for updates}

(c) Author(s) (or their employer(s)) 2019. Re-use permitted under CC BY-NC. No commercial re-use. See rights and permissions. Published by BMJ.

For numbered affiliations see end of article.

\section{Correspondence to} Dr Hemantha Amarasinghe; hemanthaamarasinghe@yahoo. com

\section{ABSTRACT}

Objective Cancer of the oral cavity is the leading malignancy among males in Sri Lanka, and sixth among women. This study aimed to estimate costs of managing patients with oral cancer (OCA) in Sri Lanka for a 12 month period from diagnosis.

Design Hospital based costing study.

Settings Four selected cancer treatment centres in Sri Lanka.

Participants Sixty-nine OCA patients: 60 were males and 12 had recurrent tumours.

Outcome Societal perspectives (healthcare, household and indirect costs) were itemised. Costs to the healthcare system included surgery, Intensive Care Unit (ICU) care, chemotherapy and radiotherapy. Capital costs including apportioned value of land, buildings, equipment and furniture. Household costs consisted of out of pocket expenditure for healthcare and indirect costs of lost income. Costs were estimated from the stage of presentation for treatment to 1 year of follow-up. Results Mean cost of managing a single stage II OCA patient for 1 year was Sri Lankan rupees (SLR) 58979 (US\$394, at the midyear exchange rate in 2016) to the health system. Mean household cost was SLR 77649 (US\$518). The annual cost of managing a stage III or IV patient was SLR 303620 (US\$2027), with household costs of SLR 71932 (US\$480).

Conclusions Owing to the high incidence of OCA in Sri Lanka, the economic costs associated with these diseases are enormous, resulting in negative impacts on both the healthcare system and individual families, seriously impacting the country's economy. Policy-makers should take note of this burden and increase steps for prevention and control of this devastating disease.

\section{INTRODUCTION}

Oral cancer poses a huge challenge to the well-being of people worldwide, and more specifically in the Asian region. Here we define oral cancer as malignant neoplasms of lip, tongue and mouth (OCA). Taken together, these cancers were estimated to affect 354864 people worldwide in 2018, with 177384 deaths. ${ }^{1}$ Fifty-six per cent of the world's oral and pharyngeal cancer burden
Strengths and limitations of this study

- A unique methodology was developed to collect costing data in low socioeconomic settings.

- This methodology could be replicated in similar countries with high prevalence of oral cancer.

- Arbitrary depreciation and personnel rates were taken due to unavailability of government validated costing algorithms.

- Cost calculations could be incomplete due to missing records.

(excluding nasopharyngeal carcinoma) is from Asia. The incidence of oral cancer for men was estimated at 14.8 per 100000 population per annum in Globocan 2018. Incidence of oral cancer among men in Sri Lanka was 15.6 per 100000 population as reported in $2014 .{ }^{2}$ Oral cancer accounts for nearly $10 \%$ of reported cancers with the highest mortality rates of all cancers in Sri Lanka. ${ }^{2}$

Both incidence and prevalence approaches have been used to assess the costs of cancer care across the globe. The incidence-based approach assesses the costs of new cases reported in a year and then adds life-time costs. The prevalence-based approach assesses all new and old cases known in a single or particular year. Life-time costs include all expenditures from diagnosis to death. Several examples of the costs of managing head and neck cancer have been published from developed countries: A cross-sectional study from New Zealand reported that cost as NZ\$22694 per patient. ${ }^{3}$ In England, the cost of treating oral and oropharyngeal carcinoma was $£ 213$ million for a 5 year period. The cost of treatment for oral and oropharyngeal carcinoma in the USA per patient was reported as US $\$ 13513$ for each stage IV case over 3 years. ${ }^{4}$

In Sri Lanka $3.5 \%$ of Gross Domestic Product is spent on the health budget. Of that, Sri Lankan rupees (SLR) 5945.5 million 
(2.3\% of the current health expenditure) were spent in treating neoplasms. ${ }^{5}$ Sri Lanka provides a totally free healthcare service to all citizens. There is no published information on the cost of care for OCA patients in Sri Lanka. This study aims to establish this information by conducting a costing exercise within the Sri Lankan health system.

\section{METHODS}

A descriptive cross-sectional study with cost analysis was conducted using activity-based costing with cost apportionment and step-down costing approach. The study was conducted in selected cancer treatment centres in Sri Lanka; the University Dental Hospital Peradeniya (PDH), Apeksha Hospital, Maharagama and Oro-maxillofacial units of General Hospital Kalutara and Kegalle. As both Apeksha Hospital and PDH are centres of excellence for treatment of OCA and treat most of the cases in the nation, it was important to include these two institutions. Two oral and Maxillofacial treatment units were selected randomly from the 25 units across the nation. Sixty nine patients with histopathological confirmation of OCA were selected for study. These patients had squamous cell carcinomas of the oral cavity, arising from the buccal mucosa, retro-molar areas, oral (anterior two-thirds) of the tongue, floor of the mouth, hard palate or lips: these are the common sites, with abuse of areca nut, smokeless and smoked tobacco, and alcohol, often in a background of diets deficient in essential macronutrients and micronutrients as the main risk factors: Human Papilloma Virus-driven cancers are not prominent in these sites in this population. ${ }^{6}$ Malignancies of the nasopharynx, oropharynx, hypopharynx and other pharynx were excluded.

Trained personal were used for data collection. Patients admitted to the oncology or onco-surgery wards for treatment during the year 2016 were recruited. All patients had a minimum of 1 year follow-up with data being collected throughout a 12-month period. Information regarding the type and stage of the disease, treatment procedures and other related details were obtained from patient records. An interviewer-administered questionnaire was used to collect information from the patients regarding their sociodemographic situation and indirect costs incurred.

The study considered two major types of cost: health system costs and household costs. Health system costs included recurrent and capital costs. Recurrent costs consisted of overhead activities (such as utility and supportive services and administrative personnel), intermediate activities (such as salaries of clinicians, medicines and consumables) and costs associated with clinic visits. Capital costs included land value, buildings and equipment. Apportionment of the times of personnel, equipment depreciation, utility services and supportive services to the activity were derived from discussion with experts in the field: medical specialists and personnel involved in these activities. Cost information of the hospital (salaries, utility and supportive services, equipment purchases and equipment values) were obtained from account ledgers, financial reports, pay sheets and expenditure reports of financial departments of the hospitals. Costs of drugs and consumables were obtained from price lists of the Medical Supplies Division of government. Service-related details were obtained from annual statistical bulletins of the hospitals.

Household costs consisted of direct and indirect costs. Direct costs constituted all the components of out-ofpocket expenditures during the study period for medicines, investigations, travel and food. Indirect costs included opportunity cost for the patient and his/her main carer which were incurred due to clinic visits or hospital days. Opportunity cost per day was calculated by dividing the monthly income of such individuals by days per month (30 days). A standardised data collection form was used to record this information.

Face and content validity were ensured by pilot testing of the checklist and questionnaire in Apeksha Hospital with patients other than OCAs and discussions with experts in the field. Cost data were collected from records in various administrative and financial offices, and from patients when collecting data for household costs. A $10 \%$ sample of the questionnaires was rechecked with clinic and BHT records by the first author to enhance the validity and reliability of data.

\section{Data analysis}

The opportunity cost of personnel time per minute was derived by dividing their monthly basic salary by minutes per month [30 (days) x 24 (hours) x 60 (min)]. For each intermediate activity, total cost per investigation or procedure was calculated and for each final activity (Clinic, Ward and ICU) cost per patient per day was calculated. Finally, for each patient, a list of final and intermediate activities and number of times that the patient underwent each activity for a period of 12 months were listed using a standard data collection format. The patient cost was the cumulative cost of all these activities. Patients were interviewed to obtain out of pocket expenditure, transport costs, and other indirect costs. Total costs per patient per day, for patients diagnosed with different stages of OCA, were calculated separately. Costs for inward patients and OPD patients who attended review clinics were derived separately.

\section{Patients and public involvement}

Patients were not involved in the development of the research questions and design stage of the study. Overall results were returned to patients during the quarterly meetings of the 'Voice of Blue Pea' Patient Group which is an oral cancer victim group established in the main cancer treatment centres in Sri Lanka.

\section{RESULTS}

Of 69 OCA patients, 60 were male. Age ranged from 40 to 81 years and $78 \%$ of the patients were less than 60 years of 
Table 1 Sociodemographic characteristics OCA patients

\begin{tabular}{|c|c|c|}
\hline Characteristics & OCA patients & Percentage \\
\hline \multicolumn{3}{|l|}{ Sex } \\
\hline Male & 60 & 87.0 \\
\hline Female & 9 & 13.0 \\
\hline \multicolumn{3}{|l|}{ Age } \\
\hline Years $40-50$ & 17 & 24.6 \\
\hline $50-60$ & 30 & 43.5 \\
\hline $60-70$ & 12 & 17.4 \\
\hline Above 70 years & 10 & 14.5 \\
\hline \multicolumn{3}{|l|}{ Education } \\
\hline No formal education & 7 & 10.1 \\
\hline $\begin{array}{l}\text { Up to general certificate of } \\
\text { education (GCE) ordinary/ } \\
\text { level exam }\end{array}$ & 55 & 79.7 \\
\hline $\begin{array}{l}\text { GCE advanced level and } \\
\text { postgraduate }\end{array}$ & 7 & 10.1 \\
\hline \multicolumn{3}{|l|}{ Stage of diagnosis } \\
\hline Stage II & 6 & 8.7 \\
\hline Stage III & 37 & 53.7 \\
\hline Stage IV & 26 & 37.7 \\
\hline Recurrences & 12 & 17.4 \\
\hline Total & 69 & 100 \\
\hline
\end{tabular}

OCA, oral cancer.

age. Most $(66 \%)$ patients were from disadvantaged backgrounds. Twelve patients had presented with recurrence. Only six OCA patients were in stage II, the remainder being stage III and IV (table 1). Eighty per cent of the OCA patients reporting to these cancer treatment centres were chewers of betel quid, $48 \%$ were smokers and $67 \%$ were consuming alcohol regularly. Among the areca nut/ betel-chewing patients, the mean number of quids chewed was 6.9 quids per day (range 0-25); mean number of cigarettes and/or Bidi sloked was four per day (range 0-25).

The present study also assessed the average monthly income and average expenditure on presumptively deleterious lifestyle habits. Average monthly income of the OCA patients was SLR 20669 (US\$138) and SLR 3003 (US\$20) was spent on betel quid chewing monthly (table 2). On average, a total of SLR 10299 (US\$69) was spent monthly by each of the $40 \%$ of patients who practiced these habits. This amounts to approximately half of each patient's average monthly income.

The mean cost of managing a stage II oral cancer patient was SLR 136628 (table 3). The highest portion of this was the health system cost. Direct and indirect household cost was higher than the health system cost. A patient had to bear about $28 \%$ of the total cost paying as out of pocket expenditure and $41 \%$ total cost as direct treatment-related expenses.

Cost of managing stage a 111 and $1 \mathrm{~V}$ patient with oral cancer was higher than a stage II patient. The total cost
Table 2 Average monthly income and money spent on habits by OCA patients

\begin{tabular}{ll}
\hline $\begin{array}{l}\text { Monthly income and expenditure } \\
\text { for lifestyle habits }\end{array}$ & $\begin{array}{l}\text { Amount in SLR (range } \\
\text { in SLR) }\end{array}$ \\
\hline $\begin{array}{l}\text { Monthly income } \\
\text { Average patient monthly income }\end{array}$ & $\begin{array}{l}20669(800-150 \text { 000) } \\
(U S \$ 138)\end{array}$ \\
\hline $\begin{array}{l}\text { Patients household average } \\
\text { monthly income }\end{array}$ & $\begin{array}{l}24728(4000-150000) \\
(U S \$ 165)\end{array}$ \\
$\begin{array}{ll}\text { Average expenditure for habits } \\
\text { Monthly expenditure for areca nut/ }\end{array}$ & $3003(300-10740)$ \\
betel quid chewing & $(U S 20)$ \\
\hline $\begin{array}{l}\text { Monthly expenditure for tobacco } \\
\text { smoking }\end{array}$ & $3214(0-10500)$ \\
Monthly expenditure for & (US $\$ 21)$ \\
consumption of alcohol & $4082(0-22400)$ \\
\hline
\end{tabular}

OCA, oral cancer; SLR, Sri Lankan rupees.

per patient was SLR 375551(table 4). The highest cost portion was borne by the health system. The out-of-pocket cost for the patient was $8.7 \%$ of the total cost.

\section{DISCUSSION}

This is the first study in calculating cost of OCA in the South Asian region where oral cancer is highly prevalent. We found very high out-of- pocket costs for all patients, most of whom are from low socioeconomic backgrounds. The methodology developed in this study can be of relevance to similar economies in calculating cost of any diseases.

Compared with the other cancers, OCA is a preventable cancer because of its strong association with habits of areca nut/betel quid chewing, tobacco use and alcohol misuse. The majority of OCAs which present in low and Middle Income countries arise from a potentially malignant disorder. Unfortunately, most patients with OCA present with advanced disease. ${ }^{7}$ Every year around 1500-2000 new cases of OCA are diagnosed in Sri Lanka, ${ }^{2}$ where almost all patients then receive treatment from State hospitals. As the country has universal free health services, costs are borne by government. In addition, the patient and his/her immediate family have to bear many indirect costs which can be catastrophic for them. To date, no proper cost analysis has been done in the country to identify the actual direct and indirect cost for the management of OCA and to compare it with preventive measures to identify the cost effectiveness.

The study attempted to calculate total costs of management of different stages of OCA for the first time in Sri Lanka. The hospital records of many of these patients were incomplete, and no billing system was in place in the hospitals. Use of advanced investigations, types of surgeries performed, use of radiotherapy and chemotherapy, vary from centre to centre, and operator to operator. Facilities in State sector hospitals are severely 
Table 3 The health system cost and household cost of managing single stage II oral cancer patient for 1 year

\begin{tabular}{|c|c|c|}
\hline Cost category & Item & Cost in SLR \\
\hline \multicolumn{3}{|l|}{ System } \\
\hline \multirow[t]{8}{*}{ Recurrent cost } & Clinic visit & 273 \\
\hline & Dental extraction & 337 \\
\hline & X-ray & 532 \\
\hline & Lab & 636 \\
\hline & Ward management & 7983 \\
\hline & Surgery & 41946 \\
\hline & Surgery consumables & 202 \\
\hline & Follow-up clinic visit & 3000 \\
\hline \multirow[t]{4}{*}{ Capital cost } & Land & 145 \\
\hline & Building & 158 \\
\hline & Furniture & 1585 \\
\hline & Total & 1888 (US\$13) \\
\hline \multicolumn{3}{|l|}{ Household cost } \\
\hline \multirow[t]{4}{*}{ Direct cost (Out Of Pocket Expenditure) } & Medicines/investigations & 18200 \\
\hline & Travel & 11249 \\
\hline & Food & 8839 \\
\hline & Total & 38287 (US\$256) \\
\hline \multicolumn{2}{|l|}{ Total cost } & 136629 (US\$912) \\
\hline
\end{tabular}

SLR, Sri Lankan rupees.

limited, leading to suboptimal use of diagnostic and staging investigations, and many of the treatment modalities used may have been far from international standard. Costs derived may not represent ideal outcomes from the patient perspective, but reflect the actual situation in the nation. Many costs may have been underestimated due to the difficulties in collecting accurate information from hospital records. Similar difficulties have been reported by others in collecting accurate cost data. ${ }^{8}$

For a patient with stage II OCA, system cost of management was approximately SLR 58979 (US\$93.72) and household cost around SLR 77649 (US\$518). For a patient with stage III or IV disease, system cost was around SLR 303620 (US\$2027) and household cost around SLR 71932 (US\$480). We did not encounter cases with stage I OCA for cost analysis but can reasonably assume that it is less than stage II cases. This finding is consistent with the findings of other similar studies. ${ }^{89}$ Our results highlight the importance of early diagnosis of oral cancer, not only to improve survival and the patient's quality of life, but also to minimise costs to the health system.

In Greece in 2002, the average cost of treatment for a patient with OCA was estimated to be US\$7450 ( SLR $1200000)^{8}$ whereas in the Netherlands in 2001, it was US\$ 22080 (SLR 3315000) ${ }^{10}$ and in the USA in 1998, it was reported as US\$32500 (around SLR 4875000). ${ }^{11}$ In the present study, the average cost for management of OCA was much lower, SLR 350000 ( US\$2300). In India, ${ }^{12}$ average treatment cost for OCA was calculated at $\sim 146000$ Indian rupees ( SLR 375000 or US\$2400), similar to our values, although the majority of patients in the Indian study were stages 1 and 11. Advanced rehabilitation of surgically treated patients, such as dental and facial prostheses were not provided to this cohort of 
Table 4 The health system cost and household cost of managing a single stage III and IV oral cancer patient for 1 year

\begin{tabular}{|c|c|c|}
\hline Cost category & Item & Cost in SLR \\
\hline \multicolumn{3}{|l|}{ System cost } \\
\hline \multirow[t]{14}{*}{ Recurrent cost } & Clinic visit & 273 \\
\hline & Dental extractions & 337 \\
\hline & Dental restorations & 415 \\
\hline & Scan & 255 \\
\hline & CT scan & 1094 \\
\hline & Lab & 1062 \\
\hline & Ward management & 7983 \\
\hline & Surgery & 50383 \\
\hline & ICU investigation & 998 \\
\hline & Radiotherapy & 55818 \\
\hline & Chemotherapy & 63683 \\
\hline & Follow-up clinic visit & 3000 \\
\hline & Staff overhead cost & 527 \\
\hline & Total & 301731 (US\$2011) \\
\hline \multirow[t]{3}{*}{ Capital cost } & Land & 145 \\
\hline & Building & 158 \\
\hline & Furniture & 1585 \\
\hline \multirow[t]{6}{*}{ Indirect costs } & Patient stay home & 8858 \\
\hline & Patient_ward days & 8176 \\
\hline & Patient clinic & 8176 \\
\hline & Carer cost ward & 7840 \\
\hline & Companion clinic visit & 6311 \\
\hline & Total & 39362 (US\$263) \\
\hline Total cost & & 375551 (US\$2507) \\
\hline
\end{tabular}

SLR, Sri Lankan rupees.

patients. If the nation can move to provide such services, much higher costs will be incurred.

\section{CONCLUSION}

The cost of management of OCA patients in Sri Lanka is extremely high, in relation to mean per capita income and national Gross Domestic Product. This has negative impacts on both the healthcare system and on individual families and impacts the national economy. Most patients affected by this devastating disease are in low socioeconomic category, burdening their families with catastrophic financial consequences. Early identification can reduce the cost of management of OCA significantly. Policy-makers should take note of this burden and take immediate and effective steps to improve primary prevention and early detection of OCA.

Author affiliations

${ }^{1}$ Institute of Oral health, Maharagama, Sri Lanka 
${ }^{2}$ Menzies Health Institute Queensland, and School of Dentistry and Oral Health, Griffith University, Queensland, Australia

${ }^{3}$ Department of Oral Medicine and Periodontology, Faculty of Dental Sciences, University of Peradeniya, Peradeniya, Sri Lanka

${ }^{4}$ Education, Training and Research unit, Ministry of Health, Colombo, Sri Lanka ${ }^{5}$ Department of OMF Surgery, Faculty of Dental Sciences, University of Peradeniya, Kandy, Central, Sri Lanka

${ }^{6}$ Oral Health Sciences, Faculty of Dentistry, Oral and Craniofacial Sciences, King's College, London, United Kingdom

${ }^{7}$ Australian Centre for Health Services Innovation, Queensland University of Technology, Brisbane, Queensland, Australia

Acknowledgements We gratefully acknowledge University of Peradeniya, Grant No. 2013/22. We acknowledge Dr Lakshmi Somatunga, Deputy Director General (MS1) for permission to conduct the study at Apeksha Hospital, Maharagama and other General Hospitals. We thank consultant oncologists at Apeksha Hospital, Maharagama and the Oral and Maxillofacial surgeons Dr Suresh Shanmuganatha and Dr Kamal Kumara for allowing us to use their patient details. We acknowledge Mr Dinesh Kumara for assisting with data entry and Drs GU Pahalavithana, S Gunawardana, A Gaythri and C Jayasinghe for help with data collection.

Contributors All authors designed the study, generated hypotheses, interpreted the data and critically reviewed the manuscript. HA analysed the data and wrote the first draft, RDJ contributed in data collecting and writing and editing the manuscript, DD and SK developed the data collection tools and developed the methodology. MA participated in data collection and in editing the manuscript, NJ and PAS advised on study design and edited the manuscript. All authors approved the final version.

Funding University of Peradeniya, Grant No. 2013/22.

Competing interests None declared.

Patient consent for publication Obtained.

Provenance and peer review Not commissioned; externally peer reviewed.

Data sharing statement Data are available upon request to the corresponding author HA through email.

Open access This is an open access article distributed in accordance with the Creative Commons Attribution Non Commercial (CC BY-NC 4.0) license, which permits others to distribute, remix, adapt, build upon this work non-commercially, and license their derivative works on different terms, provided the original work is properly cited, appropriate credit is given, any changes made indicated, and the use is non-commercial. See: http://creativecommons.org/licenses/by-nc/4.0/.

\section{REFERENCES}

1. Ferlay JEM, Lam F, Colombet M, et al. Global cancer observatory: cancer today. Lyon, France: International Agency for Research on Cancer. 2018 https://gco.iarc.fr/today (Accessed 24 Jan 2019).

2. National Cancer Control Programme. Cancer Incidence data Sri Lanka. 2014 www.nccp.health.gov.lk/index.php/publications/cancerregistries (Accessed on 30 Jan 2019).

3. Jayakar R, Choi J, MacKinnon C, et al. The cost of major head and neck cancer surgery. N Z Med J 2017;130:111-9.

4. Keeping ST, Tempest MJ, Stephens SJ, et al. The cost of oropharyngeal cancer in England: a retrospective hospital data analysis. Clin Otolaryngol 2018;43.

5. Health Economics Cell MoH, Nutrition \& Indigenous Medicine Sri Lanka (2016). Sri Lanka national health accounts 2013. Sri Lanka, Colombo: The Ministry of Health, 2016. ISBN: 978-955-0505-76-0.

6. Johnson NW GB, Speicher DJ, Ray C, et al. Etiology and Risk Factors, Chapter 2 in Shah JP and Johnson NW. Oral and Oropharyngeal Cancer, Second Edition, CRC Press. 2018 https:// www.crcpress.com/Oral-and-Oropharyngeal-Cancer/FACS-MDSc/p/ book/9781498700085.

7. Alahapperuma LS, Fernando EA. Patient-linked factors associated with delayed reporting of oral and pharyngeal carcinoma among patients attending national cancer institute, Maharagama, Sri Lanka. Asian Pac J Cancer Prev 2017:18:321-5.

8. Zavras A, Andreopoulos N, Katsikeris N, et al. Oral cancer treatment costs in Greece and the effect of advanced disease. BMC Public Health 2002;2:12.

9. Han S, Chen Y, Ge X, et al. Epidemiology and cost analysis for patients with oral cancer in a university hospital in China. BMC Public Health 2010;10:196.

10. van Agthoven M, van Ineveld BM, de Boer MF, et al. The costs of head and neck oncology: primary tumours, recurrent tumours and long-term follow-up. Eur J Cancer 2001;37:2204-11.

11. Funk GF, Hoffman HT, Karnell LH, et al. Cost-identification analysis in oral cavity cancer management. Otolaryngology-Head and Neck Surgery 1998;118:211-20.

12. Goyal S, Tiwari VK, Nair KS, et al. Risk factors and costs of oral cancer in a tertiary care hospital in Delhi. Asian Pac J Cancer Prev 2014;15:1659-65. 